This is the post-peer reviewed final draft version of the following article: Heeks, R. \& Stanforth, C. "Understanding e-government project trajectories from an actor-network perspective", European Journal of Information Systems, 16(2), 165-177, 2007, which has been published in final form at: http://www.palgravejournals.com/ejis/journal/v16/n2/full/3000676a.html

\title{
Understanding e-government project trajectories from an actor-network perspective
}

\author{
Richard Heeks ${ }^{1}$ \& Carolyne Stanforth ${ }^{1}$ \\ ${ }^{1}$ Development Informatics Group, IDPM, University of Manchester, UK \\ Correspondence \\ Richard Heeks, Development Informatics Group, IDPM, University of Manchester, \\ Precinct Centre, Manchester, M13 9QH, UK. \\ Tel: +44 161275 2800; \\ E-mail: richard.heeks@manchester.ac.uk
}

\begin{abstract}
A number of models have been offered to help explain the trajectories of egovernment projects: their frequent failures and their rarer successes. Most, though, lack a sense of the political interaction of stakeholders that is fundamental to understanding the public sector. This paper draws on actor-network theory to provide a perspective that is used to explain the trajectory of an e-government case study. This perspective is found to provide a valuable insight into the local and global actornetworks that surround e-government projects. The mobilisation, interaction and disintegration of these networks underpins the course of such projects, and can itself be understood in relation to network actor power: not through a static conception of "power over" others but through the dynamic enacted concept of "power to". As well as providing a research tool for analysis of e-government project trajectories, the local/global networks approach also offers insights into e-government leadership as a process of network formation and maintenance; and into the tensions between network stabilisation and design stabilisation.
\end{abstract}

Keywords: e-government; IS success; IS failure; actor-network theory; politics 


\section{Introduction}

It is estimated that some US\$3 trillion will be spent on information technology (IT) by governments during the decade of the 2000s (Gubbins, 2004). Yet much of this investment seems likely to go to waste with estimates of the proportion of egovernment projects failing in some way ranging from 60 percent (Gartner, 2002) through 60-80 percent (UNDESA, 2003a) up to 85 percent (Symonds, 2000). A key research issue, then, for the e-government field is to develop a better understanding of e-government project trajectories: an understanding of why some projects progress to success while others end in failure.

This is an issue that e-government researchers have already begun to investigate, typically making use of frameworks from the information systems (IS) literature. Some have adopted a factoral approach related to sets of variables/critical success factors identified in IS projects (e.g. Hazlett \& Hill, 2003) or to models that aggregate the relations between such factors (e.g. Pawlowska, 2004); others have made use of conceptual models applied in information systems such as institutionalism (Barco Serrano, 2004) or value-chain infrastructure (Beynon-Davies, 2005).

Where past investigations have been limited, however, is in their consideration of the political in e-government - of the way in which different stakeholders in an egovernment project relate to one another via political processes such as coalition and conflict. This may have occurred because of the tendency of e-government researchers to draw more from the information systems discipline rather than from the domains of governance such as political theory and public administration (Heeks \& Bailur, forthcoming). But it does represent an important gap given that e-government projects - like all initiatives in the public sector - involve the "politicking" of multiple stakeholders (Peled, 2000).

In this paper, we seek to address this gap by using a conceptual base drawn from actor-network theory that provides an explicit understanding of the political interactions of stakeholders involved with an initiative. Our central purpose, then, is to ascertain if this actor-network perspective can help develop insights into the trajectories - whether success or failure - of e-government projects. We begin with an overview of actor-network theory, identifying particularly those aspects that are applied in the subsequent sections to an e-government case study. From this we draw some findings about an actor-network perspective on the trajectories of e-government projects.

\section{Literature Review}

The selected framework for analysing e-government project trajectories is drawn from actor-network theory (ANT). The "actor-network" as a concept was developed by Michel Callon, Bruno Latour and John Law during the course of the 1980s as a recognition that entrepreneurs build networks combining technical, social and economic elements and that these heterogeneous elements, including the entrepreneurs, are, at the same time, both constituted and shaped in those networks. 
ANT writers typically develop their arguments in an empirical context. By telling stories and tracing histories rather than taking snapshots, ANT proves itself as "a pragmatic, recursive sociology of process with an interest in the uncertain processes that generate power and size" (Law, 1999). The analysis of stories in ANT leads to a better understanding of the establishment and the evolution of power relationships, because all the fluctuations that occur are preserved in these histories (Callon, 1986). This therefore seemed to be a potentially-appropriate means for understanding the process of e-government implementation that can engage with a political and stakeholder perspective.

Despite the common terminology of "actor-network theory", it might be more appropriate to think of an actor-network "perspective" that provides a worldview for a rather loosely-bounded set of writings and ideas. Around the margins of application has been literature that sees itself as inspired by some aspect of ANT, using an idea or a terminology but not applying any specific framework to its analysis. To date, the very limited use of ANT to analyse e-government falls into this category such as work incorporating within a much greater whole an idea such as inscription (Josefsson \& Ranerup, 2003) or enrolment (Beynon-Davies, 2006) to help understand roles in egovernment projects.

To understand an e-government project trajectory, however, one may need to look beyond a flavouring of ANT, to the direct application of a specific framework. The most commonly-applied within the IS literature is Callon's (1986) "moments of translation". Based on his analysis of a project attempting to restock the scallop beds in St. Brieuc Bay in Northern France, this identifies four "moments of translation" that can occur during within a multi-actor project:

- Problematisation: one focal set of actors seeks to define problems of other actors' in their own (focal actors') terms, and suggests that the solution to those problems is an "obligatory passage point" (a path from problem via single solution to goal) of the focal actors' proposed programme of activities.

- Interessement: the focal actors seek to act to lock others into their place in the network proposed within their (focal actors') programme of activities; such action may include the attempt to break competing relations that other actors may have.

- Enrolment: the focal actors seek through physical actions and negotiations to define and coordinate the roles of other actors.

- Mobilisation: the focal actors seek to ensure that the specific representatives of the other actors come to be accepted as representative of those actors; and that they (the focal actors) come to be accepted as the main voice that speaks on behalf of all actors in the network.

Callon reflects one of the cornerstones of an actor-network perspective by invoking a generalised symmetry that should allow equal treatment of human and non-human actors - including technology - within any network analysis. Not surprisingly, then, the moments of translation framework has been picked up by those studying technology implementation and, for example, applied to analysis of a number of information systems (e.g. Mähring et al, 2004; Ramiller, 2005; Sarker et al, 2006). Our literature review did not reveal any explicit applications to e-government, but the framework has been occasionally used for analysis of related topics such as public sector health information systems (Atkinson, 2000; McGrath, 2002) or public taxation systems (Madon et al, 2004). 
Our own interest, though, was drawn to a different framework from the ANT literature - Law \& Callon's (1992) local/global network framework. This framework is explained below but it seemed potentially attractive in our attempt to explain the selected e-government case for two main reasons. First, it was specifically developed to help explain project trajectories, the core interest of this paper. Second, it seemed potentially to deal well with the shifting focus, actors and fortunes of a project over time; perhaps better than the moments of translation framework which has tended to be more uni-linear at least in its application to IS analysis. The local/global network framework seems to have been little used to date (Gasson, 2006 was the only identified IS application, in which it forms one sub-component separate from the central theme), with no apparent use in e-government project analysis.

\section{Local/Global Networks Framework}

Law \& Callon's (1992) analysis of the fate of the TSR.2 project - an attempt in the UK during the 1950s and 1960s to build a new military aircraft - centres on two different forms of network that can be found in a project. The global network in a project is that set of relations "that is built up, deliberately or otherwise, and that generates a space, a period of time, and a set of resources in which innovation takes place." (ibid.: 21). This can be seen as the "outside" of the project; that which enables it to take place with the resources provided including money, expertise and political support. The local network is that set of relations "necessary to the successful production of any working device." (ibid.:22). This can be seen as the "inside" of the project; the relation of actors which actually implements the project.

Items such as project documents, physical artefacts and other deliverables are "intermediaries" that pass between actors - particularly passing from local network actors to global network actors. If there is a single locus that controls such transactions between the two networks, the ANT terminology "obligatory point of passage" is utilised.

Law \& Callon then propose that the trajectory of a project - whether it ends in success or failure - "is a function of three interrelated factors" (ibid.:46):

- $\quad$ "the capacity of the project to build and maintain a global network that will for a time provide resources of various kinds in the expectation of an ultimate return."

- "the ability of the project to build a local network using the resources provided by the global network to ultimately offer a material, economic, cultural, or symbolic return to actors lodged in the global network."

- $\quad$ "the capacity of the project to impose itself as an obligatory point of passage between the two networks."

In the case of the TSR.2 aircraft, the project ultimately failed because neither the global nor the local networks could be successfully built and maintained over the long periods required to deliver a major public sector project. It is possible to plot the changing strength of each network over time on a two-dimensional graph (see Figure 1) where the $\mathrm{x}$ axis measures the degree of mobilisation of local actors and the $y$ axis the extent to which global actors are linked. In the case of the TSR.2, a project that initially grew into the top-right quadrant ultimately descended into the bottom-left quadrant (and cancellation). 
Figure 1 - Mobilisation of local and global networks (Law \& Callon, 1992)

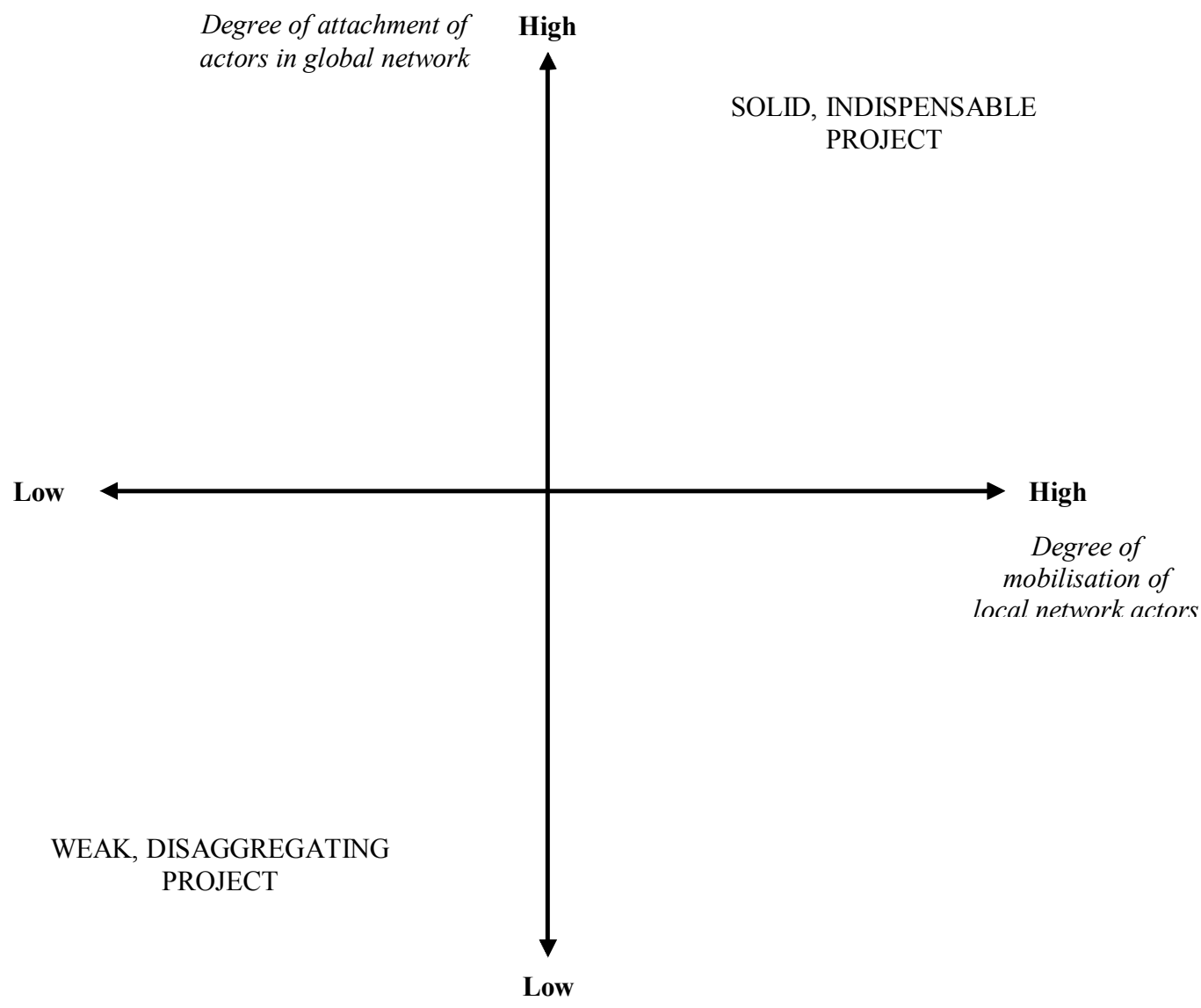

According to Law \& Callon's (1992) analysis, network maintenance may be hampered by the lack of a clear obligatory point of passage. This occurred in the TSR. 2 case, where there was "seepage" between the local and global networks that undermined each: actors in the global network were able to interfere with the structure and shape of the local network; local network actors were able to consult directly and independently with individual global network actors.

This can come about due to the inability of a dominant global network actor to impose on others its own view of the project and of the attendant roles of other actors. To understand this, one may see that those who are powerful in a network are not those who hold power in principle but those who practically define or redefine what holds everyone together. For Latour (1986), then, the issue of power is encapsulated in the following paradox: when you simply have power - in potentia - nothing happens and you are powerless; when you exert power - in actu - others are performing the action and not you. Power over something is a composition that is made by many - the primary mechanism - and attributed to one - the secondary mechanism. The amount of power exercised varies depending on the number of others who enter into the network.

At least in theory, then, this type of perspective seems as if it might be helpful for understanding the trajectory of e-government projects. As well as incorporating a 
notion of the political, the notion of a global and a local network of actors is one that arises - albeit often implicitly - within many e-government projects. In studies of local e-government, for example, the range of local actors is typically complemented by a set of broader institutional forces from central government, civil society, and the IT sector that provide the space and resources for action (see, for example, Bannister, 2003; Wagenaar \& Soeparman, 2004). Likewise, e-government applications in developing countries are often significantly affected by a truly global network of funders, vendors and consulting firms (Madon et al, 2004; Heeks, 2005). More generally, any e-government project will have a "global" set of resource providers and a "local" set of implementers. We therefore move next to instantiate the stated purpose of this paper: to see whether the local/global network perspective within ANT can be helpful in understanding the trajectory of a selected e-government project.

\section{Case Study}

\section{Methodology}

In seeking to understand the trajectory of e-government projects from an actornetwork perspective, we felt it would be necessary to select a project with a trajectory suitable for longitudinal analysis, and in which there was clarity about the presence of a global resource-providing network. We therefore selected an ongoing e-government project within Sri Lanka's Ministry of Finance. This is a project with a long historyinitial groundwork was begun in 1996 - in which a global network of both international and national players is evident.

Our overall research approach is therefore that of the case study, focused on the specifics of IT usage for financial management in one specific public sector organisation. A case study methodology "examines a phenomenon in its natural setting, employing multiple methods of data collection to gather information from one or a few entities (people, groups, or organizations)." (Benbasat et al. 1987:370). Our research strategy therefore involved a number of different research methods.

One method was based around author Stanforth's position, from September 2000 to July 2003, as a member of the international consultant team working on financial reform in the Sri Lankan public sector. She worked directly on process improvement and capacity-building in one part of the Ministry of Finance, and was thus continuously engaged with those in international and national institutions working on the e-government elements reported here.

During this project involvement, she was not actively engaged in deliberative cycles of conceptual reflection and action. However, she did record data informally through a diary process, and formally through internal documentation for the project. Hence, this is seen as an engagement of participant observation rather than action research; with participant observation seen as compatible with case study method (Akkermans \& Van Helden, 2002; Easterby-Smith et al, 2002).

This method was supplemented by analysis of documentary evidence made available through access to the full range of documentation related to the specific case application of e-government. In all, then, three types of documentation were analysed 
- an author-written diary, author-developed documentation on financial reform, and project documentation on the e-government application. Finally, the participant observation and document analysis methods were complemented by interviews with key project stakeholders. These interviews were carried out in Sri Lanka during six weeks of field visits undertaken from October 2003 to November 2005. Twenty-four interviews were held in total covering senior officials responsible for project leadership and facilitation, mid-level officials responsible for project implementation, and representatives from local consulting, international consulting and donor agencies.

The research approach used therefore provides two types of triangulation/crosschecking. First, it uses multiple methods for data-gathering. Second, it uses multiple sources of data. This type of triangulated approach is consistent with other ANTrelated field studies generally (McGrath, 2002; Madon et al, 2004). More specifically, it draws data from sources related to both local and global network actors; seen as a critical element in implementing Law \& Callon's framework (though they themselves provide no details of research method in their original work).

\section{Case Overview and History}

The focus of this case study is an e-government project called the Integrated Financial Management Information System (IFMIS); an application of IT in the Sri Lankan government intended, as the name suggests, to integrate various different aspects of financial management into a single application. As analysed below, its story is broken into four main phases: an initial package design; the rejection of that design; the organic growth of a system that could form the basis for a new IFMIS; and the recognition of a new way forward for IFMIS based on a customised approach. We start, though, with the pre-IFMIS background.

\section{Phase "Zero": Pre-IFMIS (Pre-1999)}

During the latter half of the 1990s, the Asian Development Bank (ADB) - an international financing institution involved with development projects in many Asian countries - provided funds to Sri Lanka's Ministry of Finance (MoF) to help with improvements to the Ministry's information systems. One result was the Computerised Integrated Government Accounts System (CIGAS), a project led by the Ministry's State Accounts Department. This was a system implemented in more than 2,000 locations that collected financial data from across Sri Lanka's public sector and fed it into the central Treasury Accounting System (TAS) that automated the production of the periodic accounting statements produced by government. The CIGAS/TAS project was then Sri Lanka's largest computerisation programme. It "raised significantly the skill levels of civil servants and, by working towards the control, accountability and transparency of government finances, created the enabling environment in which an effective public expenditure information system can be built" (PricewaterhouseCoopers, 2000).

\section{Phase One: Package IFMIS Proposal (1999-2001)}

Once the first generation of computerisation had been achieved, the ADB in the late 1990s urged the Ministry of Finance that its next step should be to implement a 
modern integrated financial management information system: an e-government system that would cover all aspects of the Government's expenditure management functions - namely, budgeting, accounting, treasury and debt management - and integrate them "into a cohesive system on a common database" (ADB, 1999).

Grant-funded design and preparation for this e-government project was agreed between the Bank and Ministry of Finance leadership, with the intention that the project would afterwards be implemented with the financial assistance of a follow-up loan from the Bank. Ambitions and expectations of the organisational transformation to be achieved through the IFMIS were very high among both ADB and Ministry officials, as reported by the ADB technical specialist responsible for agreeing the project design with the MoF leadership:

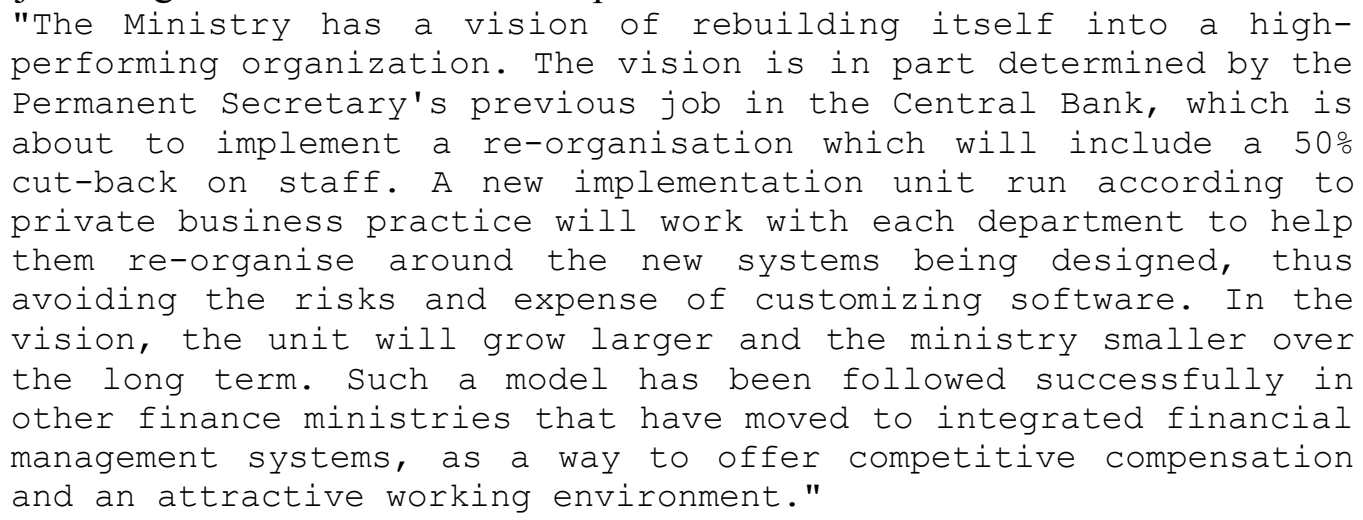

This technology-centred vision of using the e-government system to push radical reengineering was supported through the engagement of consultants from an international accounting firm. Their first report - an information systems strategy for the Ministry - endorsed the idea of an integrated e-government financial application and recommended the Ministry should move quickly to international best practice in public expenditure management, based on state-of-the-art IT and a packaged software solution costing US\$40m initially and US\$2 m per year thereafter.

\section{Phase Two: Failure of Initial IFMIS Proposal (2001)}

Once this strategy was delivered to the various stakeholder groups involved, it became clear that it did not represent something to which all had signed up. The various government line ministries and the Ministry of Finance departments that would be involved in implementing the IFMIS application felt little or no ownership. They were unwilling to second counterpart staff to work with the consultants full-time as was required by the project strategy. There was uncertainty about the procedural changes that they would need to make to accommodate to the technology-led developments recommended by the consultants. One departmental IT manager thus commented:

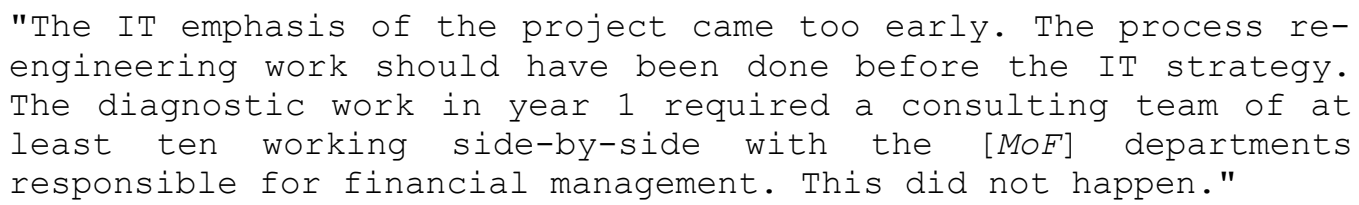

Departmental heads in the MoF, advised by the IT Unit of one department - State Accounts - judged that the recurrent costs of the envisaged system (which would have 
to be borne by the Ministry not by the ADB, which would pay for the initial investment only) were prohibitively high. They also complained to the ADB that this "big bang" type of approach failed to recognise "the accomplishments of CIGAS and other systems developed by the MoF" (ADB, 2001).

Given this lack of a shared vision for e-government, the MoF leadership had to request an urgent review of the project and, responding to this crisis, the ADB despatched a senior delegation to Sri Lanka in 2001. Following a series of intensive meetings with the involved stakeholders, the project was extensively re-designed and a new Logical Framework document - which laid out intended project goals and deliverables - was developed during their two-week mission.

\section{Phase Three: Building Foundations for a new IFMIS (2002-2003)}

Having deconstructed the original e-government project, it then had to be reconstructed. This began with a change in project actors. The ADB technical specialist was replaced by an administrative officer, and the consultancy lead switched from the international arm to the national office of the accounting firm, who were willing to locate their consultants in an office within the Ministry. The Ministry appointed a full-time Project Director as a single point of contact. It was his specific responsibility to work with the consultants to prepare the progress reports that would inform the periodic reviews undertaken by a joint MoF-ADB committee. There was also some change of senior officials in the MoF following a change of government that had occurred at the very end of 2001 .

The new LogFrame document, its associated resources and the new actors focused during 2002 and 2003 on two main activities. First, procedural changes that would eventually lead to adoption of International Public Sector Accounting Standards (IPSAS). Second, the development of much less ambitious e-government systems intended to support these procedural changes. New actors were also brought in international advisers working within the national accounting consultancy firm; and the Institute of Public Finance and Development Accountancy (IPFDA) that provided nationwide training and support in financial management issues.

There were some fairly rapid results. One of these was the implementation of a Network Operations Centre (NOC) in the Ministry of Finance that provided network infrastructure and internet connectivity to around 300 staff. As the IT manager in one MoF department commented:

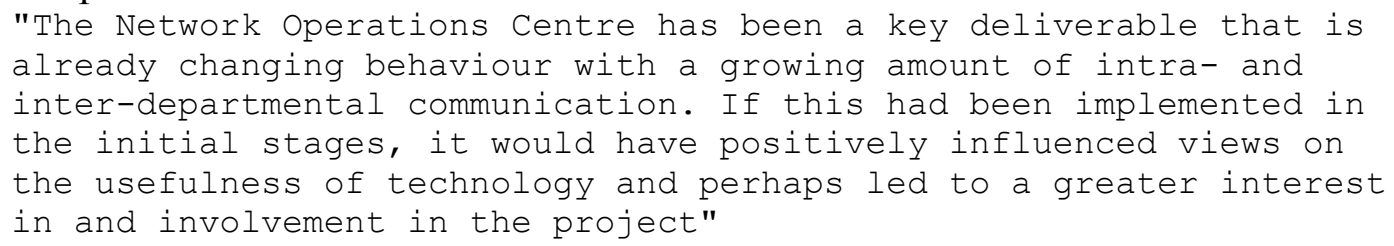

New computerised financial statements were also produced, as described by the chair of one of the project working groups:

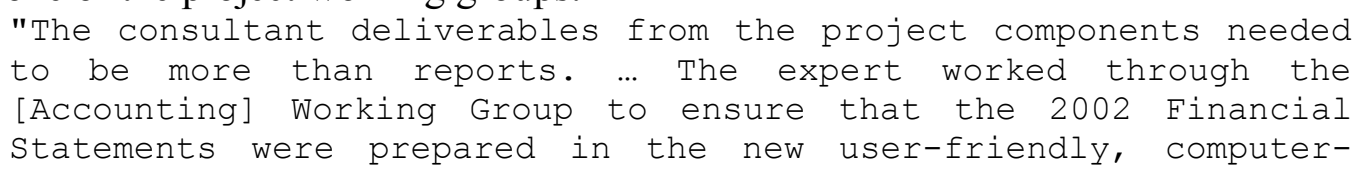


generated and IPSAS-compatible format that he had recommended. This is a very important development."

The computer generation of these statements was made possible by the development of web-enabled information systems, developed by the national accounting firm, that built on rather than replaced the Ministry's custom-developed systems, CIGAS and TAS. In particular, the Integrated Budget System (IBS) was designed to interface with the CIGAS/TAS accounting systems and hence budget preparation and execution information became available to the MoF and line ministry users from one single source.

As well as delivering a one-stop source of financial information, the IBS was also popular with the Treasury Secretary, the MoF's most senior civil servant. It chimed generally with the new Prime Minister's interest in promotion of ICT production and use in Sri Lanka (Weerakoon, 2004). It chimed more specifically with two objectives of Sri Lanka's new national ICT Steering Committee, on which the Treasury Secretary sat. First, the objective of moving to higher stages of e-government; interpreted then as moving from publication to interaction to transaction (UNDESA, 2003b) Mid-way through 2003, the IBS was shown off by Finance Ministry officials at Sri Lanka's first national E-government Conference, claiming it to be the country's first interactive egovernment application (Sri Lanka Financial Times, 2003). Second, the objective of using e-government to support the growth of national software capabilities; because IBS was a home-grown e-government application, contrasting with the more-typical approach of applications being developed by foreign consultants.

\section{Phase Four: A Revived IFMIS Proposal (2003-2005)}

As the revised ADB-funded project drew to a close, the network of Sri Lankan actors that had been brought together during Phase Three put forward a proposal for a future medium-term programme. The prime motivators of this proposal were staff in the Ministry of Finance and IPFDA, but they sought input from a number of institutional and individual actors across government. Ministry officials and others had been sensitised by the development of the Integrated Budget System to the operational value of integrated information systems facilitating inter-departmental data flows and working procedures. Support therefore coalesced around the idea of building on the Integrated Budged System in order to create an integrated e-government application for finance, similar to the earlier-proposed IFMIS. This was intended to act as the foundation for full adoption of International Public Sector Accounting Standards and Ministry officials built this idea of an integrated e-government solution into their 2003-2007 reform plan.

The Asian Development Bank remained supportive of the broad goals of financial reform, and it negotiated a new loan package during this period targeted at revenue management enhancement and sustaining the process of improving budget and expenditure control procedures in the MoF. However - perhaps "once bitten, twice shy" - initially-promised support for the integrated e-government proposal did not materialise. The ADB loan package, when it became effective in early 2005, notably failed to cover a contribution to an IFMIS (ADB, 2004). 
Knowing that its main resourcer would not be supporting these e-government plans, the Ministry of Finance was forced to look elsewhere. It began discussions on financing the development and implementation of an IFMIS with South Korea's bilateral aid agency. This led to a team of Korean consultants moving into the Ministry to undertake a design study. Their recommendation was a bilateral grant to be used to tailor an IFMIS that had recently been built for the Korean government to the requirements of the Sri Lankan government. This differed somewhat from the more "organic" "IBS-plus" development that the Ministry of Finance had in mind. Drawing on technical advice from the World Bank, MoF leadership therefore requested an initial pilot project prior to a decision being made on whether to adopt the recommended strategy. By late 2005, when the field work for this case study was concluded, the outcome of the pilot and a decision were still awaited.

\section{Case Analysis}

\section{Local and Global Networks}

Despite covering a five-year period, the chronological account just given can still be seen as just a moment in time in which the focal e-government application - IFMIS has yet to be built. Nonetheless, there is a trajectory here - of ambitious design; the apparent failure of rejection; organic developments; and then a return to something like the original idea. Can we then use the ANT framework of local/global networks to help explain this e-government trajectory? 
Figure 2 presents an overall analysis of the networks as per the Law \& Callon approach, explained in more detail below.

Figure 2 - E-government case project network analysis

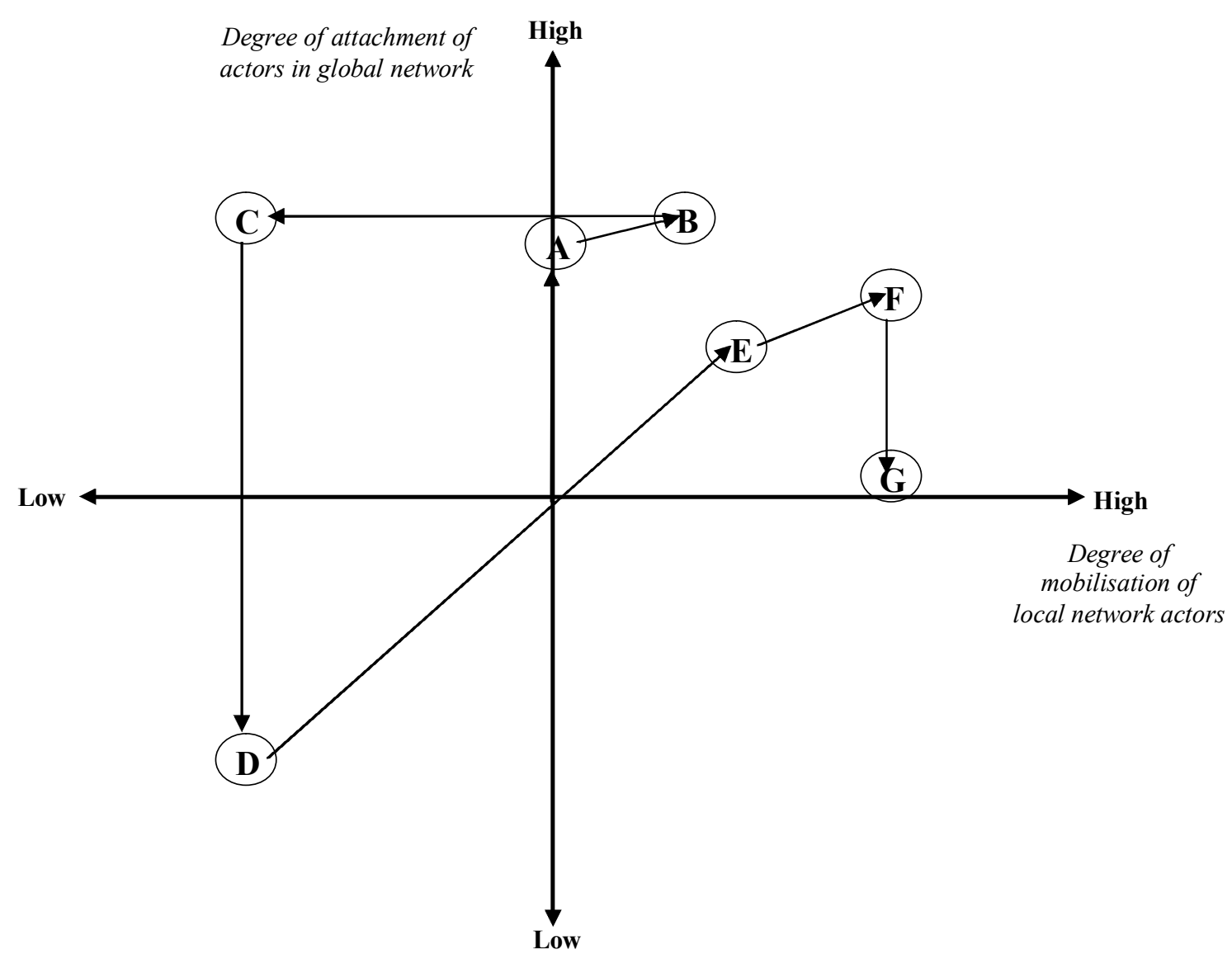

The project started when the Ministry leadership and ADB senior staff agreed a mutually acceptable objective of improved public expenditure management based on international best practice, which was broadly translated into the need for an integrated e-government solution (the initial IFMIS). Thus a global network was formed (point A) and it made resources and conceptual space available for the innovation to take place. The project was delineated and elements of a local network were mobilised (B) with the appointment and action of a team of consultants versed in international best practice.

Further progress in the formation of a local network was, however, not possible. Efforts to enrol other potential local network actors only served to make clear their lack of acceptance of the proposed IFMIS as an obligatory point of passage. The existing technology actor - CIGAS/TAS - was explicitly excluded by the consultants who were the only functioning part of the local network. Other potential members such as line ministry and MoF departmental officials - self-excluded. It thus became apparent that there was very limited mobilisation of local network actors (C). This led to withdrawal of attachment of the global network actors - first the leaders of the 
Ministry of Finance and then Asian Development Bank staff - leading to a disintegration of the global network that had sought to progress the initiative (D).

Reconstruction of both global and local networks was fairly rapid (E). The new global network centred around new officials in the ADB and Ministry of Finance. The new local network centred around the newly-engaged Ministry of Finance staff, the new national accounting firm consulting team, and staff from the Institute of Public Finance and Development Accountancy. As they were produced, the project deliverables - the local area network, the web-enabled Integrated Budget System, the new financial statements - helped further mobilise the local actors, support the membership of global network actors, and also to draw in others such as the IT manager of the Ministry's National Budget Department, which was responsible for developing the IBS (F). They were mobilised not merely towards the general notion of financial system reform but also towards specific reconsideration of an integrated e-government solution for financial management. The ultimate failure of the Asian Development Bank to provide resources for this e-government application weakened the global network $(\mathrm{G})$. It drove the Sri Lankan actors into the arms of the Korean agency, but with some uncertainty about the match between the Sri Lankan and the Korean IFMIS proposals.

\section{Networks and Project Trajectory}

From charting the process of network building, disintegration and re-building, one can then see how the trajectory of this e-government project has been shaped by the nature of the global and local networks and their inter-relation. The project was initially moving towards successful implementation in Phase One. A global network of coinciding interests had been mobilised around an agreed concept for innovation. This global network created a space for action and provided a set of resources: not just money but also the more political resources of support and legitimacy for this approach to e-government. The negotiation space provided by this initial definition of the project goals gave privacy to the local network members (the consultants), freedom from interference, autonomy and control over their work in preparing a strategy document in line with their expectations of what the global network required. The space generated by the global network also created a boundary that blocked out potential counter-interests.

Had an effective local network been created by enrolling other stakeholders then it could have generated a range of intermediaries to be passed back to the global network in return for resourcing - a more specific design of the IFMIS e-government application followed by e-government project implementation deliverables. However, the ambitious e-government application design failed to establish itself as an obligatory point of passage. It was not seen by potential local network members - the very people who would have to implement it - as the means by which they would achieve their goals. Attempts to control the local network by global network members were also lacking, as the subsequent Phase Three Project Director pointed out:

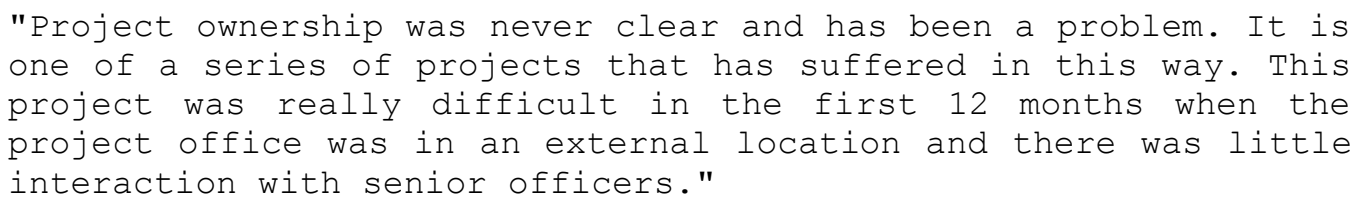


The failure to mobilise a local network, the failure of the initial strategy to establish itself as an OPP between the networks, and the "blowback" of local network failure that led the global network to then disintegrate - all these can be seen to underlie the trajectory of failure of this e-government application.

The benefit of a longitudinal approach, though, is that it helps to place any snapshot evaluation in perspective. Certainly the e-government design as envisaged in 2000 could be accounted a failure in 2001. But then a renewed global network populated by different actors was able to reform and create a new space for local network action. The boundaries of this new space - delineated in the new Logical Framework document - were more attuned to the interests of new local network actors (partly due to the participative process by which that document had been created). It thus established itself as an obligatory point of passage between the networks. Not only this but its enactment led to the creation of a series of artefacts (network infrastructure, new financial statements, Integrated Budget System) that acted in two ways. First, they were intermediaries passed back to the global network that met with global network approval (particularly in the case of the IBS in providing nationwide positive publicity for the Ministry of Finance at the E-government Conference). Second, they enrolled both local and global network actors to the idea that an "IBSplus" e-government application design would be desirable.

This enrolment was strengthened through the introduction of a single Project Director who would act as the control and communication point between local and global networks. This helped avoid the dangers of seepage; making it more difficult for direct contacts between local and global network members that were not routed through the Director. The Project Director's presence helped to ensure that the deliverables of the local network matched the interests of the global network, and that the global network would claim broader recognition for those deliverables. The Project Director also ensured a continuous stream of other intermediaries passed from local to global network in order to maintain the attachment of those global network members:

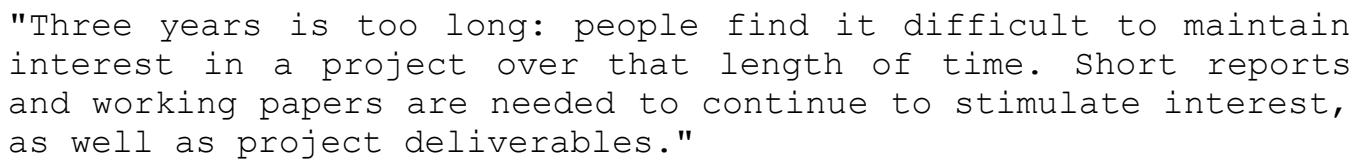

We leave the story in mid-flow and cannot say whether or not this new technology design will ultimately be implemented, particularly given uncertainties introduced by the involvement of the Korean aid agency. However, we can say that the relative success of the design indicated at point $\mathrm{F}$ was a reflection of the relative homogeneity and mobilisation of both local and global networks, and of the acceptance of the "IBSplus" e-government design as an OPP holding the networks together.

The interest here has been the trajectory of the e-government application; specifically looking at the way in which the social has shaped the technological, with this being summarised in Table 1. We should add, though, that an actor-network perspective sees the social and the technological as interwoven. Hence, it recognises ways in which the technological shapes the social, as seen in the way that the technical infrastructure and applications introduced during Phase Three shaped the interests of actors and, hence, network mobilisation. As an example, without this, it is possible 
that the proposed Korean e-government solution might well have been adopted without any piloting programme or move to customise the application to the specific needs of the Sri Lankan public sector.

Table 1 - E-government project trajectory as a function of networks and interrelations

\begin{tabular}{|c|c|c|c|}
\hline $\begin{array}{c}\text { E-GOVERNMENT } \\
\text { SOLUTION } \\
\text { TRAJECTORY }\end{array}$ & $\begin{array}{c}\text { ENROLLED NETWORK } \\
\text { ACTORS }\end{array}$ & $\begin{array}{c}\text { NON-ENROLLED } \\
\text { NETWORK ACTORS }\end{array}$ & $\begin{array}{l}\text { NETWORK INTER- } \\
\text { RELATIONS }\end{array}$ \\
\hline $\begin{array}{l}\text { Phase 1: Package } \\
\text { IFMIS Proposal } \\
\text { - Standard solution } \\
\text { - Real-time } \\
\text { processing } \\
\text { - High-speed } \\
\text { communication } \\
\text { network } \\
\text { - Integrated systems }\end{array}$ & $\begin{array}{l}\text { Global Network: } \\
\text { - MoF leadership focused on } \\
\text { organisational } \\
\text { transformation } \\
\text { - ADB focused on IT-enabled } \\
\text { public sector reform } \\
\\
\text { Local Network: } \\
\text { - International consultants } \\
\text { focused on delivery of } \\
\text { international "best practice" } \\
\text { solution }\end{array}$ & $\begin{array}{l}\text { Potential Local Network } \\
\text { [blocked]: } \\
\text { - MoF State Accounts } \\
\text { Department concerned } \\
\text { about loss of } \\
\text { CIGAS/TAS progress } \\
\text { and high recurrent costs } \\
\text { - Other MoF departments } \\
\text { and line ministries } \\
\text { uncertain about costs, } \\
\text { benefits and procedural } \\
\text { changes }\end{array}$ & $\begin{array}{l}\text { - Project not accepted } \\
\text { as OPP } \\
\text { - Lack of intermediaries } \\
\text { between global and } \\
\text { potential local } \\
\text { network actors } \\
\text { - Non-enrolled counter- } \\
\text { interests blocked by } \\
\text { space created by } \\
\text { global network }\end{array}$ \\
\hline $\begin{array}{l}\text { Phase 2: Initial } \\
\text { Proposal Failure }\end{array}$ & $\begin{array}{l}\text { Global Network: } \\
\text { - MoF leadership and visiting } \\
\text { ADB team accept non- } \\
\text { viability of initial proposal } \\
\text { Local Network: } \\
\text { - MoF departments and line } \\
\text { ministries focused on failure } \\
\text { of initial proposal }\end{array}$ & $\begin{array}{l}\text { Potential Local Network } \\
\text { [blocked]: } \\
\text { - International suppliers } \\
\text { still focused on initial } \\
\text { solution }\end{array}$ & $\begin{array}{l}\text { - Initial proposal failure } \\
\text { and new project } \\
\text { direction largely } \\
\text { accepted as OPP } \\
\text { - LogFrame document } \\
\text { as key intermediary }\end{array}$ \\
\hline $\begin{array}{l}\text { Phase 3: New } \\
\text { Foundations } \\
\text { - Internet/Web } \\
\text { infrastructure } \\
\text { - Simple Web- } \\
\text { enabled data } \\
\text { collection and } \\
\text { reporting } \\
\text { - Interface to } \\
\text { CIGAS/TAS } \\
\text { systems }\end{array}$ & $\begin{array}{l}\text { Global Network: } \\
\text { - MoF leadership focused on } \\
\text { local solutions and visible e- } \\
\text { government leadership } \\
\text { - ADB focused on longer- } \\
\text { term procedural change } \\
\text { Local Network: } \\
\text { - MoF departments and } \\
\text { IPFDA focused on } \\
\text { implementation of internal } \\
\text { e-government application, } \\
\text { and changes to accounting } \\
\text { procedures }\end{array}$ & $\begin{array}{l}\text { Global Network [partly } \\
\text { blocked]: } \\
\text { - ADB uncertain about } \\
\text { short-term e- } \\
\text { government application }\end{array}$ & $\begin{array}{l}\text { - LogFrame document } \\
\text { largely accepted as } \\
\text { OPP } \\
\text { - IBS and other } \\
\text { deliverables as key } \\
\text { intermediaries } \\
\text { - Network relations } \\
\text { routed via single } \\
\text { Project Director }\end{array}$ \\
\hline $\begin{array}{l}\text { Phase 4: Revived } \\
\text { IFMIS Proposal } \\
\text { - Customised } \\
\text { solution } \\
\text { - Real-time } \\
\text { processing } \\
\text { - High-speed } \\
\text { communication } \\
\text { network } \\
\text { - Integrated systems }\end{array}$ & $\begin{array}{l}\text { Global Network: } \\
\text { - MoF leadership focused on } \\
\text { integrated system solution } \\
\text { - Korean aid agency focused } \\
\text { on re-use/export of Korean } \\
\text { e-government system } \\
\text { Local Network: } \\
\text { - MoF departments focus on } \\
\text { integrated system built on } \\
\text { existing systems } \\
\text { - Korean aid agency staff } \\
\text { focus on customisation } \\
\text { strategy }\end{array}$ & $\begin{array}{l}\text { Global Network: } \\
\text { - ADB and World Bank } \\
\text { concern about fit of } \\
\text { Korean solution to } \\
\text { longer-term procedural } \\
\text { change }\end{array}$ & $\begin{array}{l}\text { - Local IBS-plus } \\
\text { solution initially } \\
\text { accepted as OPP } \\
\text { - Conflicting IBS-plus } \\
\text { vs. Korean designs; } \\
\text { neither fully enrolled } \\
\text { - Tension between } \\
\text { global network } \\
\text { (Korean) resource } \\
\text { provision and some } \\
\text { local network interests }\end{array}$ \\
\hline
\end{tabular}




\section{Investigating Networks and Power}

A theme of e-government has been the imposition of inappropriate external designs on different local realities (Heeks, 2006). We see this in concerns about the imposition of private sector-related designs on the public sector by IT vendors and consultants; we see it similarly in concerns about "foreign" designs being foisted on developing country governments. We can see the latter within this particular case study. And yet Phase Two represents the failure of such an attempted imposition. At first sight, this seems unusual. Actors in global networks might typically be expected to access sources of power unavailable to local network members, and thus be able to impose their solution.

Certainly that is what one might expect from a standard analysis of authoritative power in e-government projects (ibid.). The Asian Development Bank was a source of such power. It had legitimate power deriving from its formal, hierarchical authority. It had reward and coercive power from its ability to distribute or deny resources; notably funding. And it had expert power on the basis of its expertise in relation to implementation of information systems, financial management reform, and application of e-government to achieve reform goals. And yet, despite this sense in which it had "power over" other stakeholders, its initially-formulated e-government project failed. If the ability to get one's way in the face of opposition is at the heart of exercising power (Pfeffer, 1992) then our analysis shows that the ADB was not a powerful stakeholder.

Success of the Phase One project crucially depended on the mobilisation of a local network of actors, to produce an agreed e-government system. But the ADB was unable to directly influence the shape of that e-government system: it could not directly exercise power over the local network and its outputs. Why? Because, as described above, it is not the static sense of "power over" that matters - power is always in relation to something or someone else, and must be enacted. Thus what matters is the "power to" enact through others. This is a social power experienced in relationship with others and is based on an intense activity of enrolling and controlling.

For the ADB, its "power to" was limited. The sheer heterogeneity of actors in the network was one issue, making for what would have been a complex and costly enrolment process. It also faced a resistant combination of actors - both social and technical - that could not be enrolled by simple "power over". Initially, this was reflected in the combination of the State Accounts Department and its CIGAS/TAS application; later this grew by enrolling further social actors inside and outside the Ministry of Finance, and further technical actors with the development of the Integrated Budget System. In a way, then, what had been a counter-network became the main network, leaving the ADB largely to withdraw, at least from this element of financial management reform.

Likewise, with no recognised single point of control for transactions between the global and local networks during the initial phase of the project and, without a strong obligatory point of passage, the two networks operated separately from each other and came together in unplanned and unexpected ways that the ADB was unable to direct. It remained to be seen whether the Korean aid agency, with a similar "power over" 
profile to that of the ADB, could demonstrate the "power to" that can enrol and control other networks members.

\section{Conclusions}

Due to the large proportion of e-government project failures, there are uncertainties about such projects and hence a need to understand their trajectories. In this paper, we set out to ascertain if a particular actor-network perspective - based around Law \& Callon's conception of local and global networks - could help develop insights into these trajectories. We believe it has; suggesting that e-government project trajectories are a function of three things: the mobilisation of a global network of actors that resource such projects; the mobilisation of a local network of actors that implement such projects; and the imposition of the project as a single connection between these networks.

However, we also found a limitation in Law \& Callon's framework. Put simply, network mobilisation and connection may explain project trajectory, but what explains network mobilisation and connection? Here, we showed how further analysis of power in networks can be used to understand the process of network mobilisation, focused on the idea of "power to" rather than "power over". We have applied these ideas only to one particular e-government project but there are no obvious specificities in the conceptual framing that would prevent use for other egovernment applications or locations. Indeed, this actor-network perspective offers a handle on the complexity particularly inherent to e-government projects; a complexity that arises from the broader objectives, broader accountabilities and, hence, broader networks within which public sector projects are placed as compared to those in the private sector (Pollitt \& Harrison, 1992).

\section{Broader Conclusions}

Beyond this basic synthesis of findings, though, application of the local/global network framework prompts some broader conclusions: about the nature of project trajectories; about the primacy of a "focal actor", and about technological determinism.

At the start, we characterised the trajectory of an e-government project in terms of its success or failure. The perspective offered here has shown the limitations of this view because the conventions of an actor-network perspective encourage us to take a longitudinal approach. There is a sense here in which e-government can never completely fail or completely succeed because any given application design or implementation is continuously being reformed. From the perspective of 2001, the IFMIS e-government project could be accounted a complete failure - not only a failure but apparently dead and buried. Yet, just over two years' later, as the result of a re-formation of networks and actors, something quite like it was back on the agenda having been revived, zombie-like, from its grave. Conversely, the Integrated Budget System was much acclaimed as a success in 2003 but, two years' later, its future was uncertain with the potential that it would be supplanted by a customised version of a Korean e-government application. 
Thus we should not characterise the trajectory of e-government in terms of a straightforward path into a terminus labelled "success" or "failure". Instead that trajectory is a long and ever-winding journey; one that an actor-network perspective based on the idea of local and global networks and their inter-relations, has been effective in helping explain.

Our use of the term "actor-network perspective" has been deliberate. There is a danger in seeing "actor-network theory" as a monolith; as a complex social theory with a dense vocabulary that is relatively inaccessible for research purposes (Habers, 1995). Indeed, ANT's progenitors are very much aware of this. As Callon (1999) asserts, "we never claimed to create a theory. In ANT the T is too much. It is a gift from our colleagues. I fear our colleagues and their fascination for theory".

As noted above, this rather lighter touch has been evident in information systems research to date. Some researchers have just added an AN flavour to their work, such as the idea of enrolment or the idea of multiple actors, without really engaging with the ANT literature. Others have engaged by utilising an AN analytical lens and framework but this has almost always been Callon's four-part moments of translation approach. Aside from the potential limitations of analytical monoculturalism, use of moments of translation requires a focus on a single actor within the network, seen in heroic and/or Machiavellian guise. Specifically, this does not seem to fit very well the changing responsibilities and relations identified in the current e-government project. Generally, the application of AN ideas is shifting, "from the managerial approach, which focuses on how a single actor-network is aligned by a dominating central actor ... the focus has turned to the unfolding dynamics of independent actors aligning with different but intersected actor-networks" (Hanseth et al, 2006:566). The local/global networks framework thus seems of generic value in presenting a technique that engages with actor-network concepts, that is relatively accessible in its application, and yet which can deal with the complexities of a multi-stakeholder egovernment project's trajectory.

Finally, we can see this actor-network approach as a strong rebuff to technological determinism. The technology does not determine the trajectory and outcome. Indeed, in this particular case there has been relatively limited emphasis on the technology because planning rather than implementation of the central e-government application (IFMIS) was the focal activity during the time period under study.

A counter-blast against technological determinism has been commonplace to the point of tedium in IS research conclusions for at least the past thirty years. Unfortunately, though, there is a constant need to reinvent and reemphasise this message, particularly in new fields such as e-government where there is often a conceptual "year zero" approach that both enables and requires a reinvention of conceptual frameworks; and which is reflected in the strong technological determinism seen in both research and practice (Heeks \& Bailur, forthcoming); as exemplified in this case by the Phase One proposal.

There is, then, a denial of technological and social determinism inherent in the AN perspective portrayed here, and a focus instead on the combination and mutual constitution of the social and technical. The danger of this "murky middle" is that it represents no determinism at all - a complex morass in which "anything goes" and 
nothing explains (Avgerou, 2002). The local/global networks framework offers a way out by showing how "the degree and form of mobilization of the two networks and the way in which they are connected" determine a project's trajectory (Law \& Callon 1992:47). This insight provides both analytical power and, as discussed next, practical value as well.

\section{Implications for Practice}

An actor-network perspective has allowed us to encompass many levels of analysis from the individual to organisational, from the national to the international, and this can be seen as a strength of actor-network analysis of e-government. (Indeed, following Walsham (1997), one might argue a need to spread the analytical net even wider than we have done here to encompass the broader social structures and processes within which the global network is formed, such as the international network of actors promoting e-government.) This analytical strength, though, makes it more difficult to identify practical recommendations, which typically tend to focus on action at a single level. There is similarly a tension between the equality-of-actors inherent within the local/global networks analysis, and the primacy-of-one-actor inherent in most recommendations (as well, as noted, in some applications of AN ideas).

One issue around which we can crystallise this is the mantra of requirements for "egovernment champions". Our actor-network perspective suggests that no single actor can control the trajectory of an e-government project; neither local actors nor global actors. But to make recommendations, we have to fall back on the idea of a leader if not a champion, advising that leadership in e-government projects means a number of things. It means firstly focusing less on the technology than on the combination of technology and people; and less on the design than on the implications of design. Even a technically-sound project will be ineffective if it is unable to generate an understanding of and a plan for addressing the contingent outcomes of the power relationships affecting and affected by its design and implementation.

Recognising this, one may then see a potential opposition between the stabilisation of actor-networks and the stabilisation of e-government application design (Ramiller, 2005). The dissemination of a stable design - as seen at the end of Phase One of this case study - can serve to help actors identify their own interests vis-à-vis that design. Particularly if they identify their interests as counter to those inherent in the egovernment design, they may then mobilise those interests in a way that undermines local and/or global networks. By contrast, retaining an "interpretive flexibility" of design - either something vague enough so as not to clarify counter-interests, or something "big tent" enough to encompass a broad range of interests - may help network persistence. Such flexibility of design has been seen as conflicting with ease of implementation (Gasson, 2006). However, this is not necessarily the case. For example, the NOC network of Phase Three provided a relatively flexible foundation for future applications, helped to build the actor-networks forming around the idea of a new IFMIS, yet was also relatively easy to implement.

From our analysis, e-government leadership is also seen to mean focusing less on topdown control than on processes of persuasion; and focusing less on analysing static sources of authority than on dynamic ability to handle actor-networks. The focus 
should be on creation and maintenance of an effective global network to mobilise resources, on creation and maintenance of an effective local network to implement the e-government application, and on ensuring an agreed obligatory point of passage shared by the two networks. Where this does not happen - as with the ADB - then an actor with strong institutional capacity and apparent "power over" others may be unable to drive forward a successful e-government application. This kind of actornetwork perspective may thus have a value beyond leadership. Enabling "lowerlevel" project actors to understand such a perspective may be empowering; helping them to see that their lack of traditional authoritative power may not necessarily be a barrier to influence so long as they can understand their place and role in one of the project actor-networks.

Overall, such findings should focus both e-government researchers and practitioners on groups and on politics, on the formation and membership of local and global networks, and on the way in which power in practice is exercised in such networks. They show not only how these actor-network ideas may be used for post hoc evaluation of an e-government project, but also suggest how the pattern of network formation and control may offer pre hoc insights of practical relevance.

\section{About the authors}

Dr Richard Heeks is a Senior Lecturer in Information Systems at the University of Manchester, UK. He has been a researcher, trainer and consultant on e-government since the mid-1990s. His work has focused on four main areas: success and failure of e-government projects; the relation between ICTs and public corruption and accountability; public health information systems; and understanding e-government from an organisational behaviour/politics perspective. His publications include "Reinventing Government in the Information Age" (Routledge, 2001) and "Implementing and Managing eGovernment: An International Text" (Sage, 2006). Various aspects of his work on e-government can be accessed from: http://www.sed.manchester.ac.uk/idpm/dig

Carolyne Stanforth is a technical consultant in e-government design and implementation, who has worked on internationally-financed public sector reform projects in South Asia, Eastern Europe and Africa. She is currently studying for a $\mathrm{PhD}$ at the University of Manchester.

\section{References}

AKKERMANS H and VAN HELDEN K (2002) Vicious and virtuous cycles in ERP implementation: a case study of interrelations between critical success factors. European Journal of Information Systems 11, 35-46.

ADB (1999) Technical Assistance Report TAR: SRI-32533 Proposed Technical Assistance to the Democratic Socialist Republic of Sri Lanka for Strengthening Public Expenditure Management Systems. ADB Publications Department, Manila, Philippines. 
ADB (2001) Aide Memoire: Consultation on Strengthening Public Expenditure Management Systems TA 3301. ADB, Manila, Philippines. [project document]

ADB (2004) RRP: SRI 36168 Report and Recommendation of the President to the Board of Directors on Proposed Loans to the Democratic Socialist Republic of Sri Lanka for the Fiscal Management Reform Program. ADB Publications Department, Manila, Philippines.

ATKINSON CJ (2000) The 'Soft Information Systems and Technologies Methodology' (SISTeM): an actor network contingency approach to integrated development. European Journal of Information Systems 9, 104-123.

AVGEROU C (2002) Information Systems and Global Diversity. Oxford University Press, Oxford, UK.

BANNISTER, F (2003) Turf wars: the hidden menace. In Proceedings of the $4^{\text {th }}$ European Conference on e-Government (BANNISTER F and REMENYI D, Eds), pp 31-42, MCIL, Reading, UK.

BARCO SERRANO S (2004) Significance of G2G and G2B areas in e-government projects. In Proceedings of the $4^{\text {th }}$ European Conference on e-Government (REMENYI D, Ed), pp 57-66, MCIL, Reading, UK.

BENBASAT I., GOLDSTEIN DK and MEAD, M (1987) The case research strategy in studies of information systems. MIS Quarterly 11(3), 369-386.

BEYNON-DAVIES P (2005) Constructing electronic government: the case of the UK Inland Revenue. International Journal of Information Management 25, 3-20.

BEYNON-DAVIES P (2006) Personal identity management in the information polity: the case of the UK national identity card. Information Polity 11, 3-19.

CALLON M (1986) Some elements of a sociology of translation: domestication of the scallops and the fishermen of St Brieuc Bay. In Power, Action and Belief: A New Sociology of Knowledge? (LAW J, Ed), pp 196-233, Routledge \& Kegan Paul, London.

CALLON M (1999) Actor-network theory: the market test. In Actor Network Theory and After (LAW J and HASSARD J, Eds), pp 181-195, Blackwell Publishers, Oxford, $\mathrm{UK}$.

EASTERBY-SMITH M, THORPE R and LOWE A (2002) Management Research. Sage Publications, London.

GARTNER (2002) GartnerEXP Says a Majority of E-Government Initiatives Fail or Fall Short of Expectations. GartnerEXP, Stamford, CN.

http://symposium.gartner.com/story.php.id.1367.s.5.html [accessed 22 March 2006]

GASSON S (2006) A genealogical study of boundary-spanning IS design. European Journal of Information Systems 15, 26-41. 
GUBBINS M (2004) Global IT spending by sector. Computing 8 April, p28.

HABERS H (1995) Book Review: We have Never Been Modern by Bruno Latour. Science, Technology and Human Values 20(2), 270-275.

HANSETH O, JACUCCI E, GRISOT M and AANESTAD M (2006) Reflexive standardisation: side effects and complexity in standard making. MIS Quarterly 30, 563-581.

HAZLETT S-A and HILL F (2003) E-government: the realities of using IT to transform the public sector. Managing Services Quality 13(6), 445-452.

HEEKS RB (2005) eGovernment as a carrier of context. Journal of Public Policy 25(1), 51-74.

HEEKS RB (2006) Implementing and Managing eGovernment. Sage Publications, London.

HEEKS RB and BAILUR S (forthcoming) Analyzing e-government research: perspectives, philosophies, theories, methods and practice. Government Information Quarterly.

JOSEFSSON U and RANERUP A (2003) Consumerism revisited: the emergent roles of new electronic intermediaries between citizens and the public sector. Information Polity 8, 167-180.

LATOUR B (1986) The powers of association. In Power, Action and Belief: A New Sociology of Knowledge? (LAW J, Ed), pp 264-280, Routledge \& Kegan Paul, London.

LAW J (1999) After ANT: complexity, naming and topology. In Actor Network Theory and After (LAW J and HASSARD J, Eds), pp 1-14, Blackwell Publishers, Oxford, UK.

LAW J and CALLON M (1992) The life and death of an aircraft: a network analysis of technical change. In Shaping Technology/Building Society: Studies in Sociotechnical Change (BIJKER WE and LAW J, Eds), pp 21-52, MIT Press, Cambridge, MA.

MADON S, SAHAY S and SAHAY J (2004) Implementing property tax reforms in Bangalore: an actor-network perspective. Information and Organization 14, 269-295.

MÄHRING M, HOLMSTRÖM J, KEIL M and MONTEALEGRE R (2004) Trojan actor-networks and swift translation. Information Technology \& People 17(2), 210 238.

McGRATH K (2002) The Golden Circle: away of arguing and acting about technology in the London Ambulance Service. European Journal of Information Systems 11, 251-266. 
PAWLOWSKA A (2004) Failures in large systems projects in Poland. Information Polity 9(3,4), 167-180.

PELED A (2000) The politics of outsourcing: bureaucrats, vendors, and public information technology projects. Information Infrastructure and Policy 6, 209-225.

PFEFFER J (1992) Managing with Power: Politics and Influence in Organizations. Harvard Business School Press, Boston, MA.

POLLITT C and HARRISON S (1992) Introduction. In Handbook of Public Services Management (POLLITT C and HARRISON S, Eds), pp 1-22, Blackwell, Oxford, UK.

PRICEWATERHOUSECOOPERS (2000) Strengthening Public Expenditure Management Systems Project Technical Proposal TA 3301-SRI. ADB, Manila, Philippines. [project document]

RAMILLER NC (2005) Applying the sociology of translation to a system project in a lagging enterprise. Journal of Information Technology Theory and Application 7(1), $51-76$.

SARKER S, SAONEE S and SIDOROVA A (2006) Understanding business process change: an actor-network perspective. Journal of Management Information Systems 23(1), 51-86.

SRI LANKA FINANCIAL TIMES (2003) Finance Ministry goes hi-tech: Choksy launches unique information network. Sri Lanka Financial Times 14 May.

SYMONDS M (2000) Government and the Internet, survey. Economist 355: 24 June.

UNDESA (2003a) E-government as a "free lunch"? Development Administration 106, 6-8.

UNDESA (2003b) World Public Sector Report 2003: E-Government at the Crossroads. UN Department of Economic and Social Affairs, New York.

WAGENAAR P and SOEPARMAN S (2004) Coping with the dilemma of common pool information resourcing. Information Polity 9(3,4), 181-192.

WALSHAM G (1997) Actor-network theory and IS research: current status and future prospects. In Information Systems and Qualitative Research (LEE AS, LIEBENAU J and DEGROSS JI, Eds), pp 466-480, Chapman and Hall, London.

WEERAKOON B (2004) Rendering Unto Caesar. New Dawn Press Group, Reading, UK. 